\title{
Taxation Of Mandatory Restitution Received By Victims Of Human Trafficking
}

Christine Haynes, University of West Georgia, USA

Bruce M. Bird, University of West Georgia, USA Mark Wills, University of West Georgia, USA

Adam Cleek, University of West Georgia, USA

\begin{abstract}
In Notice 2012-12, the Internal Revenue Service announced that awards of mandatory restitution received by victims of human trafficking under 18 U.S.C. 1593 of the Trafficking Victims Protection Act of 2000 are excluded from gross income. This article examines the basic provisions of the Trafficking Victims Protection Act of 2000, the calculation of mandatory restitution, publicly available resources involving human trafficking, and the taxability of damages involving physical versus nonphysical injury under civil law.
\end{abstract}

Keywords: Mandatory Restitution; Victims of Human Trafficking; Awards; Gross Income

\section{INTRODUCTION}

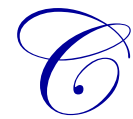

ongress enacted the Victims of Trafficking and Violence Protection Act of 2000 as part of a multi-prong strategy to help reduce human trafficking. ${ }^{1}$ In Notice 2012-12, the Internal Revenue Service announced that mandatory restitution payments awarded to victims of human trafficking under 18 U.S.C. 1593 are excluded from gross income for income tax purposes. ${ }^{2}$

\section{THE TRAFFICKING VICTIMS PROTECTION ACT OF 2000}

To help reduce human trafficking, the United States uses a three-prong strategy of prevention, prosecution and protection. ${ }^{3}$ Prevention involves encouraging economic opportunities for individuals in their country of origin. For example, micro-lending programs in some countries have allowed women to start their own businesses. Individuals who, over time, become self-sufficient are less likely to potentially fall victim to human trafficking. The second prong of this strategy involves prosecution. In United States v. Kozminski, the U.S. Supreme Court held that involuntary servitude requires "threats or acts of physical or legal coercion." Act of 2000 extends this definition to include "non-violent coercion." In addition, individuals convicted of certain crimes that involve human trafficking are now required to serve lengthier prison terms. The third prong, protection, gives victims of human trafficking access to governmental benefits under federal and state programs. In some situations, a victim of human trafficking can apply for a T-Visa or for permanent residency by participating in the investigation and prosecution of the human trafficker under investigation. ${ }^{6}$ However, a trafficking victim must be "certified" through the Office of Refugee Resettlement in order to receive various governmental benefits while in the United States.

\footnotetext{
${ }^{1}$ Victims of Trafficking and Violence Protection Act of 2000, Pub. L. No. 106-386, 114 Stat. 1464 (codified as amended in various sections of the U.S.C.). This Act is also referred to as the "Trafficking Victims Protection Act of 2000" and the "TVPA of 2000."

${ }^{2}$ Notice 2012-12, IRB 2012-6, p. 365 (2/6/12).

${ }^{3}$ See TVPA of 2000, § 102(a).

${ }^{4}$ U.S. v. Kozminski, 487 U.S. 931 (1988).

${ }^{5}$ TVPA of 2000, § 102(b)(13).

${ }^{6}$ TVPA of 2000, § 107(e)(1); Immigration and Nationality Act (INA), USC § 101(a)(15)(T).

${ }^{7}$ TVPA of 2000, § 107(b)(1)(E)(i)(II)(bb).
} 
The TVPA of 2000 has been reauthorized in 2003, 2005 and 2008. The Trafficking Victims Protection Reauthorization Act of 2003 is significant in that it allows victims of human trafficking to file civil actions in U.S. District Court in which actual and punitive damages, along with reasonable attorney fees, can be recovered. In addition, the Trafficking Victims Protection Reauthorization Act of 2005 authorizes funds to investigate and prosecute the trafficking of U.S. citizens.

\section{CALCULATING MANDATORY RESTITUTION}

A federal criminal court must order restitution to a victim of human trafficking for any offense committed under 18 U.S.C. $\S \S 1581$ through $1594 .{ }^{8}$ Under 18 U.S.C. $\$ \S 1581-1594$, Congress has defined a series of criminal acts that relate to peonage, slavery, and other forms of human trafficking. These include: "1) holding a person to a condition of peonage ${ }^{9}$ 2) kidnapping or carrying away a person to sell the person into involuntary servitude or to be held as a slave; ${ }^{10} 3$ ) providing or obtaining a person's services or labor by actual or threatened use of certain means including force, physical restraint, serious harm, and abuse of legal process $;{ }^{11}$ and iv) sex trafficking of children or by force, fraud, or coercion." 12 Thus, the award of mandatory restitution reflects the serious nature of crimes associated with human trafficking whereby some victims have been subjected to "sexual abuse, torture, starvation, imprisonment, threats, psychological abuse and coercion" 13 and forced "through physical violence to engage in sex acts or perform slavery-like labor." ${ }^{14}$

A federal criminal court is required to direct the defendant to pay the victim the full amount of the victim's losses. This includes "costs for medical services relating to physical, psychiatric, or psychological care; costs for physical and occupational therapy or rehabilitation; necessary transportation, temporary housing, and child care expenses; lost income; attorney's fees and other costs; and other losses the victim suffers as a proximate cause of the offense." " In addition, under 18 U.S.C. § 1593(b)(3), such losses include "the greater of the gross income or value to the defendant of the victim's services or labor or the value of the victim's labor as guaranteed under the minimum wage and overtime guarantees of the Fair Labor Standards Act." 16

\section{Example 1}

Defendant, a successful real estate developer from the Philippines, led a criminal operation that used fraudulently obtained visas to traffic several dozen girls from Southeast Asia into the United States. The defendant physically abused the girls, requiring them to work up to 16 hours-a-day at hair and nail salons in Los Angeles, California, and to turn over all of their earnings to him. The defendant also forced many of these girls to engage in prostitution.

A federal jury convicted the defendant on numerous criminal counts including forced labor, visa fraud, and harboring aliens. The court ordered the defendant to pay mandatory restitution of $\$ 291,000$ to each victim. Assume that the mandatory restitution is comprised of the following amounts: ${ }^{17}$

\footnotetext{
${ }^{8} 18$ USC $\S 1593(a) ; 18$ USC $\S 3663 ; 18$ USC $\S 3663$ A.

${ }^{9} 18$ USC $\$ 1583(\mathrm{a})(1)$.

${ }^{10} 18$ USC $\$ 1589(a)(1)$

${ }^{11} 18$ USC $\$ 1591$.

${ }^{12} 18$ USC $\S \S 1593$ and $112(a)$.

${ }^{13} \mathrm{Id}$.

${ }^{14} 22$ USC $\$ 7101(b)(6)$.

1518 USC $\$ 1593$ incorporating 18 USC $§ 2259$ (b)(3) by reference.

${ }^{16} 18$ USC $§ 1593(b)(3)$.

${ }^{17}$ The examples contained in this manuscript focus upon the tax consequences of damages received by victims of human trafficking. Any other tax consequences are outside the scope of this manuscript.
} 
Medical Care for Physical Injury

Medical Services for Psychological Care

Necessary Transportation

Temporary Housing

Child Care Expenses

Attorney's Fees

Lost Income

Total Payments Received
$\$ 11,000$

$\$ 70,000$

$\$ 10,000$

$\$ 8,000$

$\$ 2,000$

$\$ 20,000$

$\$ 170,000$

$\$ 291,000$

Under Notice 2012-12, all of the mandatory restitution payments received are excluded from each victim's gross income.

\section{Example 2}

Defendant, a successful businessman from the Dominican Republic, led a criminal operation that used fraudulently obtained visas to traffic several dozen underage girls into the United States. The defendant coerced the defendants by fraud and by threats of force. However, no physical violence occurred. The girls worked up to 16 hours-a-day at hair and nail salons in Anaheim, California, and turned over all of their earnings to him.

A federal jury convicted the defendant on the criminal counts of visa fraud and harboring aliens. The court ordered the defendant to pay mandatory restitution of $\$ 191,000$ to each victim as follows:

\author{
Medical Care for Physical Injury \\ Medical Services for Psychological Care \\ Necessary Transportation \\ Temporary Housing \\ Child Care Expenses \\ Attorney's Fees \\ Lost Income
}

Total Payments Received

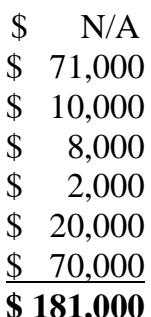

Under Notice 2012-12, all of the mandatory restitution received is excluded from each victim's gross income. Here the total amount of mandatory restitution relates to one or more offenses committed under 18 U.S.C. $\S \S 1581$ through 1594 and is excludible from gross income even though, under the facts, no physical injury occurred.

\section{PUBLICLY AVAILABLE RESOURCES}

The HumanTrafficking.org project is devoted to increasing public awareness that human trafficking is a growing problem in the United States. ${ }^{18}$ It publicizes what it describes as the "largely invisible issue of modern day slavery." For example:

[I]n 2000, Berkeley landlord and restaurateur Lakireddy Bali Reddy was charged with smuggling minors into the United States and keeping them as sex slaves. (He was later sentenced to more than eight years in prison and ordered to pay $\$ 2$ million in restitution.). Were it not for the accidental death of a 17-year-old girl brought here from India with her younger sister - the result of a malfunctioning heater in their small Bancroft Way apartment that case, which involved at least 25 girls over a period of 15 years, might never have come to light. ${ }^{19}$

\footnotetext{
${ }^{18}$ This website, originally created by the Academy for Educational Development (AED), can be found at: http://www.aed.org. In 2011, the programs and initiatives of the AED combined with those of the Family Health International (FHI), thereby creating a new entity known as FHI360 .

${ }^{19}$ This story originally appeared in The Berkeleyan. See: http://berkeley.edu/news/berkeleyan/2008/03/12_trafficking.shtml
} 
In February, 2011, the Human Trafficking Clinic at Michigan Law School launched the Human Trafficking Law Project database. ${ }^{20}$ A state-by-state search of this database found mandatory restitution awards ranging from $\$ 0$ to $\$ 3,949,140 .{ }^{21}$ It should be noted that some defendants originally charged with crimes involving human trafficking under 18 U.S.C. $\S \S 1581$ through 1594 may plead guilty to lesser offenses that do not provide for mandatory restitution. Also, some verdicts involving mandatory restitution may ultimately be overturned on appeal. Thus, it is possible for a mandatory restitution award of $\$ 0$ to be reported. Moreover, a related issue involves whether a victim of human trafficking, after having been awarded restitution by the court, will actually receive it. In other areas of the law, some eligible victims have not received restitution because the perpetrators involved lack the available resources to pay it. ${ }^{22}$

\section{EXCLUDING CIVIL DAMAGES FROM GROSS INCOME}

The Trafficking Victims Protection Reauthorization Act of 2003 provides a civil remedy to a victim of human trafficking. A victim of forced labor, ${ }^{23}$ peonage, slavery or involuntary servitude, ${ }^{24}$ or sex trafficking, ${ }^{25}$ can file a civil action in federal district court to recover actual and punitive damages along with reasonable attorney fees. It should be noted that, if available, civil restitution does not fall within the protection of Notice 2012-12. ${ }^{26}$

In general, most types of damages received from physical personal injury or sickness can be excluded from a victim's gross income. Amounts awarded by the courts as the result of a lawsuit fall into this category as do amounts received in the settlement of a lawsuit. ${ }^{27}$ Some damages that flow from physical injury or sickness, such as those relating to nonphysical injury or lost wages, can be excluded. ${ }^{28}$ Punitive damages, however, are intended to punish reprehensible conduct and to deter such conduct in the future. Accordingly, they are not excludable from gross income even if associated with physical injury or sickness. ${ }^{29}$

Under current law, in most situations, damages received from non-physical injury (e.g., age or sex discrimination) are not excludable from gross income. ${ }^{30}$ Emotional distress is considered a non-physical injury and such damages are typically not excludable from gross income (other than those damages for non-physical injury that are associated with -- and flow from -- physical injury or that relate to the cost of medical care). Compensation for lost profits is not excludable from gross income. However, disability benefits received from loss of income or the ability to earn income under a no-fault car insurance policy are excludable. ${ }^{31}$

At times, the extent to which damages received by an injured party is traceable to physical versus nonphysical injury is unclear and may result in litigation. In Eugene Amos, Jr. v. Commissioner, ${ }^{32}$ during a televised NBA game, a basketball player kicked a cameraman. Shortly thereafter, an ambulance transported the cameraman to the hospital for treatment. The cameraman later received $\$ 200,000$ from the basketball player pursuant to a settlement agreement containing a confidentiality clause. The cameraman classified the entire amount as damages received on account of physical injury or sickness and, accordingly, excluded the entire amount received from his gross income. Upon audit, the IRS included in the cameraman's gross income all but $\$ 1$ of the settlement amount he received. At trial, the Service contended that the cameraman had failed to introduce into evidence the extent of physical injuries that he received as a result of the incident, and that, in any event, such injuries were minimal.

\footnotetext{
${ }^{20}$ See: http://www.law.umich.edu/clinical/humantraffickingclinicalprogram/pages/default.aspx The United Nations Office on Drugs and Crime also maintains a database on human trafficking.

${ }^{21}$ United States v. Akouavi Kpade Afolabi.

See: http://www.justice.gov/usao/nj/Press/files/pdffiles/2010/Afolabi,\%20Akouavi\%20Kpade\%20Sentencing\%20PR.pdf

${ }^{22}$ See: http://www.lclark.edu/live/files/5653-n

${ }^{23} 18$ USC $\$ 1589$.

${ }^{24} 18$ USC $\$ 1590$.

${ }^{25} 18$ USC \$ 1591 .

${ }^{26}$ Specifically, Notice 2012-12 applies to "mandatory" restitution awarded by a criminal law court to a victim of human trafficking for any offense committed under $\S \S 1581-1594$. While restitution is a remedy typically associated with a criminal law proceeding, it can be associated with a civil one.

${ }^{27} 26$ USC $\left.\$ 104(a)(2)\right)$.

${ }^{28} 26$ USC, $§ 104(a)$.

${ }^{29}$ See Stevan v Comm'r, 80 T.C.M. 420 (2000), TC Memo. 2000-302).

${ }^{30}$ Small Business Job Protection Act of 1996, P.L. 104-188.

${ }^{31}$ See IRS Pub. 525 (2011).

${ }^{32}$ Eugene Amos, Jr. v. Commissioner, 86 T.C.M. 663, T.C. Memo 2003-329 (Dec. 1, 2003).
} 
In a memorandum decision, the Tax Court determined that the dominant reason for the settlement agreement related to the cameraman's claimed physical injuries as a result of the incident. The court noted, though, that the settlement agreement expressly provided that a non-specified portion of the settlement related to the taxpayer's agreement not to: 1) defame the basketball player; 2) disclose the existence or terms of the settlement agreement; 3) publicize facts relating to the incident; or 4) assist in any related criminal prosecution against the basketball player. In light of these facts, the Tax Court determined that $\$ 120,000$ of the $\$ 200,000$ settlement amount should be excluded from income. This decision illustrates the difficulty a taxpayer receiving a lump-sum settlement faces in apportioning damages received between physical and nonphysical injury. involved.

The following example illustrates the tax consequences of receiving damages where no physical injury is

\section{Example 3}

Defendant, a successful real estate developer from India, legally obtained visas for several dozen college graduates from India to work in the United States. The defendant coerced the girls by fraud and by threats of force to work in jobs other than those for which they were hired. However, no physical violence occurred. The girls worked up to 16 hours-a-day and turned over all of their earnings to him.

A federal jury acquitted the defendant on the criminal counts of visa fraud and harboring aliens. The girls then sued in civil court for emotional distress and for other nonphysical injuries. Each victim received the following damages:

Medical Care for Physical Injury

Medical Services for Psychological Care

Necessary Transportation

Temporary Housing

Child Care Expenses

Attorney's Fees

Lost Income

Total Payments Received

\begin{tabular}{lr}
$\$$ & N/A \\
$\$$ & 71,000 \\
$\$$ & 10,000 \\
$\$$ & 8,000 \\
$\$$ & 2,000 \\
$\$$ & 20,000 \\
$\$$ & 70,000 \\
\hline$\$ \mathbf{1 8 1 , 0 0 0}$
\end{tabular}

Here the medical services for psychological care in the amount of $\$ 71,000$ will be excluded from gross income.

\section{NOTICE 2012-12 AND NOTICE 95-31: A COMPARISON}

Notice 2012-12 is not the first situation in which the Internal Revenue Service has interpreted another source of the tax law in announcing that restitution is excludible from a victim's gross income. In Notice 95-31, the Internal Revenue Service announced that compensation paid by the government of Germany "for property confiscated by the National Socialist regime prior to or during World War II" is exempt from U.S. taxation. In issuing Notice 95-31, the Service interpreted Article 19(1)(c) of the tax treaty ratified in 1989 between the U.S. and the Federal Republic of Germany. Specifically, Article 19(1)(c) provides that:

Pensions, annuities and other amounts paid by one of the Contracting States or by a juridical person organized under the public laws of that State as compensation for an injury or damage sustained as a result of hostilities or political persecution shall be exempt from tax by the other State.

This announcement applies to both reparations and restitution involving property or compensation received by qualified claimants "whose property located in the former GDR [German Democratic Republic] was confiscated by the National Socialist [Nazi] regime."

On its website, the Internal Revenue Service states that "a notice is a public pronouncement that may contain guidance that involves substantive interpretations of the Internal Revenue Code or other provisions of the 
law. ${ }^{33}$ While it is true that the IRS has used a Notice in the past to announce that restitution can be excluded from gross income ${ }^{34}$, in that situation, a treaty existed between the U.S. and Germany for the IRS to interpret. By way of contrast, the Trafficking Victims Protection Act of 2000, as amended, neither states nor implies that mandatory restitution is excludible from a victim's gross income. In announcing that such restitution is excludible, Internal Revenue Service does not appear in Notice 2012-12 to have substantively interpreted either the Internal Revenue Code or other provisions of the law. Stated alternatively, Notice 2012-12 does not contain the rationale upon which the Service's announcement is based.

The principal author of Notice 2012-12 is Sheldon Iskow of the Office of Associate Chief Counsel (Income Tax \& Accounting). In a telephone conversation, Mr. Iskow recently indicated that Notice 2012-12 reflects "a policy call" limited to mandatory restitution awarded to a victim of human trafficking in a criminal action for any offense committed under $\$ \S 1581-1594 .{ }^{35}$ The Service could have announced in Notice 2012-12 that restitution is taxable in some situations, but that for public policy reasons, it decided not to pursue recipients of mandatory restitution payments who are victims of human trafficking under the TVPA of 2000. Instead, the Service chose to announce that such payments are excludible from gross income.

\section{CONCLUSION}

The Trafficking Victims Protection Act of 2000 is designed to help reduce human trafficking in the United States. This Act, as amended, provides for both criminal and civil damages. Under Notice 2012-12, mandatory restitution awards received under the TVPA of 2000 are excludible from gross income. Notice 2012-12 can be viewed as a "pro-taxpayer" announcement that provides welcome relief to such victims of human trafficking.

\section{AUTHOR INFORMATION}

Christine Haynes, Ph.D., is a Professor of Accounting and the Director of the Masters of Professional Accounting (MPAcc) program at the University of West Georgia. She earned her Ph.D. in Accounting from the University of Texas at Austin and her B.S. in Accounting from the University of Utah. Her primary research interest is auditor judgment/decision-making. E-mail: chaynes@westga.edu

Bruce M. Bird, JD, CPA, is a Professor of Accounting in the Richards College of Business at the University of West Georgia. He consults and writes frequently in the area of taxation. His articles have appeared in Journal of Taxation, Tax Adviser, CPA Journal, Journal of Financial Planning and many other journals. E-mail: bbird@westga.edu (Corresponding author)

Mark Wills, CPA, is a Lecturer at the University of West Georgia. He earned his MPAcc from the University of West Georgia and his B.B.A. in Accounting from Valdosta State University. His teaching interests include financial accounting, managerial accounting, auditing, and accounting information systems. He has over fifteen years of experience as a manager of IT Audit with two of the Big 4 accounting firms. E-mail: mwills@westga.edu

Adam Cleek, MPAcc, is a financial consultant with HER Concepts. He earned his MPAcc from the University of West Georgia along with his B.B.A. in both Accounting and Finance. As an entrepreneur, he has helped start three businesses and has been involved in real estate development and investment for the past eight years. E-mail: adam.cleek@hotmail.com

\footnotetext{
33 "For example, notices can be used to relate what regulations will say in situations where the regulations may not be published in the immediate future." See: "Understanding IRS Guidance - A Brief Primer" at http://www.irs.gov

${ }^{34}$ Notice 95-31, IRB No. 1995-22 (5/30/95).

35 Telephone conversation between Sheldon Iskow and Bruce M. Bird (9/24/12). On a related note, the Human Trafficking Clinical Program at the University of Michigan Law School has indicated that the advocacy of its student attorneys played a role in the Service's decision to issue Notice 2012-12. ${ }^{35}$
} 


\section{REFERENCES}

1. Eugene Amos, Jr. v. Commissioner, 86 T.C.M. 663, T.C. Memo 2003-329 (Dec. 1, 2003).

2. Immigration and Nationality Act (INA).

3. IRS Pub. 525 (2011).

4. $\quad$ Notice 95-31, IRB No. 1995-22 (5/30/95).

5. $\quad$ Notice 2012-12, IRB 2012-6, p. 365 (2/6/12).

6. $\quad$ Small Business Job Protection Act of 1996, P.L. 104-188.

7. Stevan v Comm'r, 80 T.C.M. 420 (2000), TC Memo. 2000-302).

8. The Berkeleyan. Retrieved from http://berkeley.edu /news/berkeleyan

9. Understanding IRS Guidance - A Brief Primer. Retrieved from http://www.irs.gov

10. U.S. v. Kozminski, 487 U.S. 931 (1988).

11. Victims of Trafficking and Violence Protection Act of 2000, Pub. L. No. 106-386, 114 Stat. 1464 (codified as amended in various sections of the U.S.C.). This Act is also referred to as the "Trafficking Victims Protection Act of 2000" and the "TVPA of 2000."

12. $\quad 18$ USC $\S \S 112,1583,1589,1590,1591,1593,2259,3663$.

13. 22 USC $\$ 7101$.

14. 26 USC $\$ 104$. 


\section{NOTES}

